DOI:10.17951/h.2021.55.1.19-29

\begin{tabular}{lcc}
\hline \multicolumn{3}{c}{ A N N A L E S } \\
UNIVERSITATIS MARIAE CURIE-SKŁODOWSKA \\
LUBLIN - POLONIA \\
VOL. LV, 1 & SECTIOH H \\
\hline
\end{tabular}

\title{
OLIWIA KHALIL-OLIWA
}

oliwiakhalil@hotmail.com

Silesian University of Technology. Faculty of Organization and Management

26 Roosevelt St., 41-800 Zabrze, Poland

ORCID ID: https://orcid.org/0000-0003-0033-6906

\section{Review of Risks and Risk Management Systems in the Largest Islamic Banks of the Arabian Peninsula}

Keywords: risk management; risk management systems; Islamic banks; Islamic banking

JEL: F30; G21; G32

How to quote this paper: Khalil-Oliwa, O. (2021). Review of Risks and Risk Management Systems in the Largest Islamic Banks of the Arabian Peninsula. Annales Universitatis Mariae Curie-Skłodowska, sectio H-Oeconomia, Vol. 55, No. 1.

\begin{abstract}
Theoretical background: The specificity of Islamic principles, on the basis of which Islamic banking was created, as well as the nature of its financial instruments, means that Islamic banks may be exposed to greater risks than conventional banks.

Purpose of the article: The aim of the article is to define key risks identified by Islamic banks and to define risk management systems in the 13 largest banks of the Arabian Peninsula region. The article analyses the annual reports submitted by the supervisory boards of the largest Islamic banks of the Arabian Peninsula for 2018, so that common elements in their risk management processes can be found.

Research methods: Analyses of annual reports of the banks of the Arabian Peninsula region.

Main findings: Supervisory boards of Islamic banks identify risks and implement strategies and risk management structures. The most important risks identified by banks are credit risk, liquidity risk, reputational risk, as well as operational risk, understood as the risk of direct or indirect loss, resulting from inadequate or faulty internal processes, errors of employees or systems and external events. Islamic banks may be exposed to increased credit risk, due to the application of the principle of profit and loss sharing (PLS), which is one of the pillars of Islamic finance. An analysis of the financial reports of the largest Islamic banks of the Arabian Peninsula shows that all supervisory boards are aware of the importance and role of an effective
\end{abstract}


risk management system in reducing costs and increasing banks' results. Most of them use the principles described by the Islamic Financial Services Board (IFSB). All banks have implemented appropriate risk management processes and policies, and have units in their structures responsible for the risk management process, which means that they apply the first IFSB principle. The institutions declare that they identify and monitor risks, and implement risk mitigation measures.

\section{Introduction}

In Islam, the basic sources of law, closely related to religion, are: The Koran, or holy book, which contains descriptions of revelation, social, religious and cultural system, and the Sunnah, which is a written collection of messages about the prophet Muhammad. These two sources make up the holy law of Islam - Sharia, translated as "the good path" or "the path to the source" (Danecki, 2007, p. 84).

Muslim law regulates conduct in all areas of the followers' lives, including finance and banking. Initially, Islamic banks developed only as a form of financial intermediation, directed at the Muslim community, but now they are becoming a part of the global financial system.

The foundation of Islamic banking is cooperation, integrity and assistance to community members. Thus, Islam is opposed to social injustice and exploitation. At the same time, Islamic banks should act, taking into account a number of bans and norms, and therefore face limited freedom to enter into financial transactions.

Due to the above principles, a large number of risks may appear in the operational activity of Islamic banks, and therefore the implementation of an effective risk management system seems to be key to their functioning. Risk management principles addressed to Muslim institutions were described by the Islamic Financial Services Board in 2005.

The aim of the article is to define key risks identified by Islamic banks and to define risk management systems in the 13 largest banks of the Arabian Peninsula region. Research conducted, among others, by Rosman and Rahman on a group of 32 Islamic banks from 16 countries showed that risk management practices in the Middle East and North Africa differ from those used in Asian countries (Rosman \& Rahman, 2015, pp. 150-172). Therefore, the article only analyses the annual reports submitted by the supervisory boards of the largest Islamic banks of the Arabian Peninsula for 2018, so that common elements in their risk management processes can be found.

\section{Literature review}

Islamic banking is a system of capital redistribution, consistent with the principles of modern Islamic economy, created in the second half of the $20^{\text {th }}$ century as an alternative to the conventional banking industry developing in Muslim countries. 
A special feature of this system is its hybrid character (Pietrucha, 2010, p. 191), combining, on the one hand, elements of capitalism, such as the freedom of the individual to get rich, respect for private property, with the prohibitions and orders contained in Sharia, the holy law of Islam. In addition, Islamic banks not only strive to maximise their profit, but also to multiply the resources of their customers (AlKaber, 2000, p. 48).

The basic principle of Islamic banks' operation is the Koran ban on collecting and receiving interest $(r i b a)$ from conducted financial operations (Martysz, 2013, p. 44). This is due to the belief that such actions would be in contradiction to the fair redistribution of wealth, and thus to the principles of social justice. All products and services offered by financial institutions should be based on the following principles:

- the contract may be concluded only if the parties to the contract agree to its terms of their own free will and with full awareness,

- all parties to the contract must know the consequences of its conclusion,

- the parties should ensure that they are able to fulfill the obligations arising from the contract (which is not the case when a person sells goods which they do not own),

- the parties to the contract strive to honestly fulfill its conditions (Karwowski, 2005).

The first bank, whose activity was entirely based on Islamic laws, was opened in Egypt in 1963. From that moment, Islamic banking began to develop very dynamically and in Pakistan in 1977 the entire banking system became Islamic (Al-Kaber, 2013, p. 178). In the 1990s, international financial institutions, such as Citibank, BNP-Paribas and Deutsche Bank started operating on Muslim markets. They opened branches operating under the Sharia law - the so-called Islamic windows (Martysz, 2013, p. 42). Nowadays, Islamic banks operate in about 80 countries around the world and among European countries, the most operate in Great Britain (Mikita, 2011, pp. 33-35; Global Islamic Economy Report, 2019).

Islamic banking is based on fundamental principles, affecting the operation of the Muslim financial institutions, including banks:

- ban on the use of riba - no interest (interest-free banking). If the entity assumes no risk, it cannot receive remuneration (Włodarczyk, 2013, p. 114). According to Islamic principles, interest in financial operations is unfair to the lender (when the inflation rate exceeds the interest rate), as well as to the borrower, when they fail to make a profit (Martysz, 2013, p. 48),

- prohibition of gharar - all transactions concluded in accordance with Islamic principles must be fully transparent and honest. It is unacceptable to conclude transactions in a situation of information asymmetry, in which one of the parties does not have full knowledge, e.g. about the final price and consequences. This principle also prohibits the sale of assets not owned by the seller. All contracts must be concluded on the basis of the parties' trust, primarily regarding certainty of compliance with the agreed conditions. Accordingly, 
transactions should be free from risk and uncertainty, as well as speculation, and may not bear the hallmarks of a fraud (Al-Kaber, 2013, p. 182),

- prohibition of qimar and maysir - prohibition of participating in games of chance. The transaction should be free from uncertainty and speculation, and the resulting profit cannot be known in advance. This rule also applies to trading in options and futures, as well as speculative transactions (Martysz, 2013, p. 48),

- profit and loss sharing - both the borrower and the lender should equally share the risk arising from the undertaken ventures (Al-Kaber, 2013, p. 184),

- transaction ethics (halal) - banks cannot conclude transactions related to, e.g. the construction of casinos, production of drugs or alcohol. Financial institutions should support transactions that respond to the needs of Islamic society, e.g. production of drugs, development of education (Martysz, 2013, p. 48),

- paying alms (zakat) - in accordance with one of the pillars of the Muslim religion, alms support the idea of social solidarity (Martysz, 2013, p. 49),

- applying moral principles (halal) - institutions should conduct internal audits to check compliance of all activities with the Islamic law. In practice, this rule manifests itself in the existence of special boards or departments in banks (Martysz, 2013, p. 49).

Moreover, it is worth mentioning the function of money in Islam, which affects the basis for the operation of Muslim financial institutions - money is only a means of exchange and expression of value, it cannot become a goal by itself.

Based on the above principles, Islamic banks have developed a number of financial instruments. The most popular are (Martysz, 2013, pp. 49-53; Nowak, 2010, pp. 46-60):

- mudarabah - a contract between the capital provider and the project manager, according to which the distribution of profits is based on contractual provisions, but the losses are incurred only by the financing entity. Mudarabah's structure resembles a limited partnership, whose partners are the general partner and the limited partner,

- murabahah - a short-term credit transaction, with features similar to a trade credit. The bank purchases the goods needed by the buyer or importer and then sells them at an agreed higher price. As a result, the bank acquires property rights, joining the purchase and sale transaction, thus, bearing the risk. Thanks to this, the bank is entitled to a profit,

- musharakah - a company based on the principle of sharing profits and risk taken, most similar to joint venture companies. Profits from the venture are divided based on the conditions established at the stage of signing the contract, while losses in proportion to the capital contributed,

- qard al-Hassan - a short-term free-of-charge loan, designed to support the local community. Some of the Sharia school, however, accept minor admi- 
nistrative fees charged by bank. The purpose of such financing is most often for the support in financing health care and pilgrimages,

- sukuk - bonds, the equivalent of debt securities in the Islamic world. As a result of investment failure, sukuk holders also bear the risk of loss.

The specificity of Islamic principles, on the basis of which Islamic banking was created, as well as the nature of its financial instruments, means that Islamic banks may be exposed to greater risks than conventional banks. Some commentators, however, believe that risk management is contrary to the principles of the Muslim religion, because it is a kind of bet on the result of a random event (Nowakowski \& Borowski, 2007, p. 333).

Research conducted by Hussain and Al-Ajmi (2012, pp. 215-239) on a group of 560 employees of conventional and Islamic banks in Bahrain showed that the overall level of risk facing Islamic banks is perceived as much higher than for conventional banks. It can be caused by:

- no active money markets for Islamic instruments, that are in line with Sharia,

- limited access to short-term financing options available to conventional banks,

- maintaining high cash balances from the current account balance, maintained to cover customers' demand for withdrawals from their accounts (Iqbal \& Mirakhor, 2012, pp. 275-298).

\section{Research methods}

The purpose of the article is to define the basic risks in the operations of Islamic banks and to define their risk management systems. The 13 largest banks of the Arabian Peninsula were analysed.

To identify banks, the Top Islamic Financial Institution report was used, published by The Banker, with the participation of Dubai Islamic Economy Development Centre and Dubai International Financial Centre. All of the analysed Islamic banks have been indicated as Safest Islamic Banks in Global Finance's 2020 annual ranking (Global Finance World's Safest Banks, 2020). The banks being analysed are presented in Table 1.

Table 1. The largest Islamic banks of the Arabian Peninsula in 2015

\begin{tabular}{|l|l|l|l|}
\hline $\begin{array}{c}\text { Ranking } \\
\text { position }\end{array}$ & \multicolumn{1}{|c|}{ Bank name } & \multicolumn{1}{c|}{ Country } & \multicolumn{1}{c|}{$\begin{array}{c}\text { Profit before tax USD } \\
\text { millions }\end{array}$} \\
\hline 1 & Al Rahji Bank & Saudi Arabia & $1,822.98$ \\
\hline 3 & Dubai Islamic Bank & UAE & 768.00 \\
\hline 5 & Kuwait Finance House & Kuwait & 663.00 \\
\hline 7 & The Company for Cooperative Insurance (NCCI) & Saudi Arabia & 560.12 \\
\hline 8 & Masraf Al Rayan / Al Rayan Bank & Qatar & 554.00 \\
\hline 9 & Abu Dhabi Islamic Bank & UAE & 476.00 \\
\hline 10 & Qatar Islamic Bank & Qatar & 469.00 \\
\hline
\end{tabular}


Pobrane z czasopisma Annales H - Oeconomia http://oeconomia.annales.umcs.pl Data: 26/04/2023 16:06:31

\begin{tabular}{|l|l|l|l|}
\hline $\begin{array}{c}\text { Ranking } \\
\text { position }\end{array}$ & \multicolumn{1}{|c|}{ Bank name } & \multicolumn{1}{|c|}{ Country } & \multicolumn{1}{|c|}{$\begin{array}{c}\text { Profit before tax USD } \\
\text { millions }\end{array}$} \\
\hline 13 & Al Baraka Banking Group & Bahrain & 375.00 \\
\hline 15 & Alinma Bank & Saudi Arabia & 337.00 \\
\hline 18 & Al Bilad Bank & Saudi Arabia & 230.00 \\
\hline 20 & Qatar International Islamic Bank, Doha & Qatar & 226.00 \\
\hline 22 & Barwa Bank & Qatar & 195.00 \\
\hline 25 & Al Jazira Bank & Saudi Arabia & 152.00 \\
\hline
\end{tabular}

Source: (The Banker, Top Islamic Financial Institutions, Financial Times, 2015, p. 11).

In the first stage of the research, annual financial reports were reviewed, as well as management boards' reports on operations for 2018. For banks that published corporate governance information, this was also taken into account. All documents used are publicly available via the websites of the banks. In the second stage, the types of risk, to which the bank is exposed, were identified for each of the surveyed enterprises, as well as the risk management systems at this entity.

The analysis only focused on the largest Islamic banks of the Arabian Peninsula.

\section{Results}

Supervisory boards of Islamic banks identify risks and implement strategies and risk management structures. The most important risks identified by Islamic banks are the same as risks indicated by entire banking sector. These are credit risk, liquidity risk, reputational risk, as well as operational risk, understood as the risk of direct or indirect loss, resulting from inadequate or faulty internal processes, errors of employees or systems and external events.

The report by the Saudi bank, Al Rahji Bank, indicated that the compliance with the Sharia law makes the bank immune to the risk arising from speculative transactions, such as hedging, options, forward contracts and derivatives (Al Rahji Bank Annual Report, 2018). On the other hand, there is a unique risk in Islamic banks, related to ensuring compliance of offered products and services with Sharia. Due to the lack of clear rules on banking products, each of them must be considered as not contradictory to the Islamic law by the appropriate internal structure of the bank. However, this does not mean that a product or service that has been approved in one bank will gain the approval of the supervisory board or customers in the other (Hussian \& Al-Ajmi, 2012, p. 233). Qatar's Al Rayan Bank indicates in its 2018 annual report that the lack of compliance of products or services with Sharia is associated with a risk of loss of earnings, as well as a risk of loss of reputation (Al Rayan Bank Annual Report, 2018).

Another element that increases the risk of Islamic banks in the context of the compliance of their products and services with the Sharia law is the legal risk arising from the concluded contracts. Due to their nature, banks often conclude a number of 
contracts that can lead to complications and disputes. An example of an instrument that requires a multi-stage contracting process is murabahah - a bilateral purchase and sale agreement, without financing (Hussian \& Al-Ajmi, 2012, p. 234).

Islamic banks are exposed to increased credit risk, due to the application of the principle of profit and loss sharing (PLS), which is one of the pillars of Islamic finance. This concept is based on the belief that the only way to achieve benefits is to be open to the possibility of loss. In other words, risk should be shared by both parties of the loan contracts. The PLS principle is the basis for one of the basic financial instruments of banks, i.e. mudarabah and musharakah. Both of these instruments are a form of capital partnership, in which one party contributes financial capital and the other side - its knowledge and skills. Both parties share the risk of business activity. The musharakah contract gives the financing party the opportunity to make operational decisions, while in the mudarabah contract, the financing party cannot influence the implemented venture (Iqbal \& Mirakhor, 2012, p. 304).

Basing the financial instrument on the PLS principle requires determining the level of the parties' share in profits, as well as losses. While the coverage of losses is regulated based on the Islamic law and principles, the issue of profit participation is related to the value and nature of the venture. It is important that the amount of participation is specified as a percentage, not as a quota (Piotrowski, 2014, pp. 99-113).

Risk management policies at Islamic banks were described thoroughly by the Islamic Financial Services Board (IFSB) in 2005 and are applied by banks. The document contains principles relating to basic risks that affect the operation of banks (Islamic Financial Services Board, 2005).

The first principle concerns the active role of a board member or high-level manager in risk management, consisting in ensuring the effectiveness of this process (Islamic Financial Services Board, 2005, pp. 4-5). The second principle, relating to credit risk, indicates, among others, that the bank should have appropriate methods for measuring and reporting credit risk, as well as developed mitigation measures (Islamic Financial Services Board, 2005, pp. 6-11).

Mudarabah and musharakah are described in the third principle about procedures using the PLS principle (Islamic Financial Services Board, 2005, pp. 12-15). It is also indicated that, in the case of risk related to capital investments, the bank should involve independent institutions, in order to audit and validate the investments.

Market risk management is included in the fourth principle (Islamic Financial Services Board, 2005, pp. 16-18). According to the guidelines, the bank should have an appropriate market risk management framework (including the risk reporting stage) for all assets held, including those that are exposed to high price volatility. In addition, it is important for a financial institution to develop a market risk strategy, including an acceptable level of appetite for market risk, taking into account existing contracts with suppliers, types of risk taking activities, as well as target markets, in order to maximise profits while maintaining exposure at a certain level of risk. The strategy should be periodically reviewed and communicated to relevant employees. 
The fifth principle in the guidelines relates to liquidity risk (Islamic Financial Services Board, 2005, pp. 19-22). According to it, banks should have a separate liquidity management framework for each current and investment account category. It is recommended to implement a liquidity management policy that includes reliable liquidity measurement and monitoring process, periodic liquidity exposure monitoring system and well developed liquidity crisis management principles.

Islamic banks must also have appropriate systems to identify and measure factors that pose a risk of return. Suggestions for this risk are described in principle six (Islamic Financial Services Board, 2005, pp. 23-25). IFSB guidelines encourage banks to develop new instruments that are in line with the Sharia law.

The last, seventh principle, applies to operational risk management, not only related to internal processes, employees and systems, but also to non-compliance with the Islamic law and non-compliance with obligations imposed on banks (Islamic Financial Services Board, 2005, pp. 26-28). The guidelines indicate that financial institutions should carry out cyclical checks of operational risk management to detect and resolve problems that may arise on an ongoing basis. Moreover, the IFSB emphasises the role of external audits, during which the internal control mechanisms of banks are reviewed (Islamic Financial Services Board, 2005).

An analysis of the financial reports of the largest Islamic banks of the Arabian Peninsula shows that all supervisory and management boards are aware of the importance and role of an effective risk management system in reducing costs and increasing banks' results. Most of them use the principles described by the IFSB.

All banks have implemented appropriate risk management processes and policies, and have units in their structures responsible for the risk management process, which means that they apply the first IFSB principle. The institutions declare that they identify and monitor risks, and implement risk mitigation measures.

It is worth noting that none of the banks indicated in the 2018 annual report showed that they implemented or even maintain the Enterprise Risk Management (ERM) system, which is the most holistic risk management system. The ERM is implemented at every level of the organisation and helps to improve the decision-making process and collect information effectively (Wróblewski, 2011).

The analysed annual reports show that Islamic banks have clearly defined operational risk management procedures, in particular regarding the compliance of products and services with the Sharia law. Due to the awareness of the fundamental principles of finance (including riba), banks are very cautious about all transactions. This, in turn, is a measure that mitigates reputational risk. In addition, the non-compliance with the Sharia law affects the bank's market position, its profits and financial liquidity.

The largest Islamic bank of the Arabian Peninsula is the Al Rahji Bank from Saudi Arabia, which operates within the framework defined by the Saudi Arabian Monetary Authority (SAMA). The bank has a Risk Management Committee and a Chief Risk Officer. The bank's authorities indicate that they are implementing 
risk mitigation measures, consisting in the diversification of customer segments and markets in which the Bank operates (Al Rahji Bank Annual Report, 2018).

Dubai Islamic Bank has implemented a detailed risk management model, aimed at identifying, measuring and monitoring risk. The Bank's structures include a Committee and a Department for Risk Management. Risk measurement is performed using quantitative and qualitative methods, and the implemented model includes clearly defined roles and responsibilities, as well as risk management policies and practices. This model is reviewed regularly to ensure that it meets regulatory standards and international practices.

Al Rayan Bank, the largest Islamic bank in Qatar, includes in their risk mitigation activities, among others, the review of products and services before their introduction to the market, in order to ensure continuous compliance with Sharia in all areas of activity and monitoring whether all policies, procedures and transactions comply with the principles of the Islamic law and the Bank's Code of Conduct. Moreover, the bank carries out a verification procedure of all suppliers for compliance of their activities with Sharia. Al Rayan has implemented a risk management model, that is a tool for identifying, monitoring and reporting risks (Al Rayan Bank Annual Report, 2018).

\section{Conclusions}

The aim of the article was to analyse key risks identified by Islamic banks and to define risk management systems in the largest banks of the Arabian Peninsula region. The first part presents the basic principles for the operation of banks, such as riba, gharar or maysir. In addition, the most popular financial instruments based on the principles and doctrine of the Muslim religion were presented.

Research to date indicates that the overall level of risk faced by Islamic banks is perceived to be higher, as compared to conventional banks. This may be caused by, among others, a lack of active money markets for Islamic instruments and limited access to short-term financing options. The second part of the article discusses the basic categories of risks, that are identified by Islamic banks, such as: credit risk, liquidity risk, reputational risk and operational risk. Bank-specific risk is related to the compliance of offered products and services with the Sharia law.

Risk management policies at Islamic banks have been described thoroughly by the IFSB. Although the banks follow the basic guidelines, none of the analysed banks has implemented a holistic risk management system (Enterprise Risk Management). Part four of the article analyses 13 risk management systems at the largest Islamic banks of the Arabian Peninsula, based on available financial reports for 2018. They show that Islamic banks have clearly defined operational risk management procedures, in particular regarding the compliance of products and services with the Sharia law. In addition, all supervisory boards are aware of the importance and role of an effective risk 
management system in reducing costs and increasing banks' results. The institutions declare that they identify and monitor risks, and implement risk mitigation measures. It should be noted, however, that Islamic banks do not have complex and advanced risk management systems.

The principles of Islamic banks' operation differ significantly from the conventional banking model. The idea of social responsibility, lack of interest and risk sharing are in conflict with individualism, product interest and risk transfer in conventional banks. Islamic and conventional banks also have a different purpose - the former aim not only to make a profit, but also to multiply the assets of their customers, while the purpose of the latter is mainly to maximise profit.

Although the assets of conventional banks significantly outweigh those of Islamic banks, the question arises about the possibility of cooperation between these banking models. Islamic banks offer products that are modeled on conventional products. In addition, their significant problem is determining whether a given product or service is compatible with Sharia. There is also a question of how often instruments in accordance with Koran law are used in practice. Taking the above into account, one should consider whether, in fact, Islamic banks will lose their character in the future.

On the other hand, conventional banks are showing interest in the Muslim market, opening the so-called Islamic windows. Moreover, due to the desire to diversify, the demand for Islamic banks' products and services from conventional investors may increase in the future.

The question remains, whether conventional banks should consider applying certain ethical principles of Islamic banking, such as sharing profits and losses or social responsibility. Due to the dynamic development of Islamic banks and their expansion in developed countries, it would be advisable to deepen the analysis of risk management systems contained in the article, among others by conducting a survey addressed to persons responsible for risk management systems in banks.

\section{References}

Al Rahji Bank. (2018). Annual Report. Retrieved from https://www.alrajhibank.com.sa/en/investor-relations/ documents/al_rajhi_bank_annual_report_2018_(eng).pdf

Al Rayan Bank. (2018). Annual Report. Retrieved from https://www.alrayanbank.co.uk/media/454140/ annual-report-and-financial-statements-2018.pdf

Al-Kaber, M. (2000). Istota działalności banków islamskich. Bank i Kredyt, 6, 47-53.

Al-Kaber, M. (2013). Techniki finansowe banków islamskich. Optimum. Studia Ekonomiczne, 3, 175-194.

Danecki, J. (2007). Podstawowe wiadomości o Islamie. Warszawa: Wydawnictwo Dialog.

Hussain, H., \& Al-Ajmi, J. (2012). Risk Management Practices of Conventional and Islamic Banks in Bahrain. The Journal of Risk Finance, 3(3), 215-239. doi:10.1108/15265941211229244

Global Finance. (2000). World's Safest Banks. Retrieved from https://www.gfmag.com/magazine/november-2020/gcc-safest-islamic-banks 
Global Islamic Economy Report. (2019). Retrieved from https://salaamgateway.com/reports/report-state -of-the-global-islamic-economy-201920

Iqbal, Z., \& Mirakhor, A. (2012). An Introduction to Islamic Finance: Theory and Practice. Singapore: John Wiley \& Sons (Asia) Pte. Ltd.

Islamic Financial Services Board. (2005). Guiding Principles of Risk Management for Institutions (Other Than Insurance Institutions) Offering Only Islamic Financial Services. Retrieved from https://www. ifsb.org/published.php

Karwowski, J. (2005). Uwagi na temat bankowości islamskiej. Bank i Kredyt, 9.

Martysz, Cz. (2013). Zarys problematyki finansów islamskich. Zeszyt Naukowy Kolegium Zarządzania i Finansów, 128, 41-59.

Mikita, M. (2011). Nowa era bankowości islamskiej. Przegląd Organizacji, 11, 33-35. doi:10.15290/ ose.2013.03.63.11

Nowak, P. (2010). Sukuk - alternatywne źródło pozyskiwania kapitału. Master of Business Administration, $18,46-60$.

Nowakowski, J., \& Borowski, K. (2007). Finanse islamskie - wybrane zagadnienia bankowości islamskiej i islamskich rynków akcji. In J. Węcławski, P. Karpuś (Eds.), Problemy rozwoju rynku finansowego w aspekcie wzrostu gospodarczego (pp. 333-342). Lublin: Wydawnictwo UMCS.

Pietrucha, J. (2010). Inne współczesne systemy hybrydowe. In S. Swadźba (Ed.), Systemy gospodarcze. Powstanie i rozwój (pp. 182-192). Katowice: Wydawnictwo UE.

Piotrowski, D. (2014). Zastosowanie podstawowej zasady finansów islamskich PLS celem ograniczenia zjawiska moralnego hazardu na rynkach usług finansowych. Acta Universitatis Nicolai Copernici, 1, 99-113. doi:10.12775/AUNC_ECON.2014.006

Rosman, R., \& Rahman, A.R.A. (2015). The Practice of IFSB Guiding Principles of Risk Management by Islamic Banks: International Evidence. Journal of Islamic Accounting and Business Research, 6(2), 150-172. doi:10.1108/JIABR-09-2012-0058

Włodarczyk, J. (2013). Bankowość islamska i bankowość konwencjonalna - próba porównania. Studia Ekonomiczne. Wydawnictwo Uniwersytetu Ekonomicznego w Katowicach, 145, 113-122.

Wróblewski, R. (2011). Zarządzanie ryzykiem w przedsiębiorstwie. Zeszyty Naukowe Uniwersytetu Przyrodniczo-Humanistycznego $w$ Siedlcach, 90, 9-31. 